\title{
Entrepreneurship Development and Market Orientation Model as A Strategy in Food Security in Wamena, Jayawijaya
}

\author{
Westim Ratang, Jack.H.Syauta, dan Vince Tebay \\ Universitas Cenderawasih, Indonesia \\ westim_ratang@yahoo.co.id
}

\begin{abstract}
Entrepreneurship Development and Market Orientation Model as the strategy in Food Security in Wamena, Jayawijaya.This research is aimed to discover: 1) the mindset of farmer groups (wen mina hipere) about entrepreneurship, 2) the ability of entrepreneurship and market orientation of the farmer groups, 3) The factors that affect the entrepreneurship and the orientation toward the managing ability of garden, fish and sweet potatoes. Population is a group of farmers (wen mina hipere) who work as farmers of sweet potatoes and freshwater fish culturing (carp, catfish and tilapia) that exist in the region of Silokarno Doga District, Wogi village, Wamena. The Samples are 20 farmers as determined by Proportionate cluster random sampling method. Sampling was conducted on a group of farmers (nina hipere) around Wogi village, Wamena. The type of data that will be used are: 1) primary data obtained through the interviews using questionnaire, unstructured interviews, and FGD (Focus Group Dicusion) to 20 farmers (wen mina hipere) of garden, fish and sweet potatoes. 2) secondary data will be obtained from the department of agriculture, the Wamena statistics office. The analysis used is Quantitative analysis with descriptive approach and factors analysis that influence the farmers mindset that consists of entrepreneurship and market orientation variable. The result shows that the variables (1) viewing and taking opportunities, (2) systematic planning, (3) the strategy to influence, (4) confidence, (5) persuasive ability, (6) coordination with related agencies, it does not have a significant effect on the mindset of farmers on entrepreneurship collectively. Variables that have a significant effect on the mindset of farmers on entrepreneurship are: (1) competitor orientation, (2) consumers orientation, (3) specificity, (4) orientation on efficiency, (4) work commitment, (5) Focus on high performance levels, (5) seeking information, (6) persistence and (7) initiative, they significantly and positively affect on the mindset of farmers on entrepreneurship. Dominant variables that make up the success of farmers in Wamena are persistence and work commitment. Entrepreneurship development and market orientation model that can be applied is by providing seedlings and land preparation, land cultivation mentoring, and consumer-oriented in harvest and improving coordination with related agencies for food security.
\end{abstract}

Keywords: Wenmina hipere, entrepreneurship, market orientation, diversification, agricultural land, food security

\section{Introduction}

Food insecurity in the regional level and household/individual level is failed achievement condition of food security in the regional level or households/individual's. Therefore, discussing food insecurity can not be separated from the concept of food security. Food security is a interpretation of food security, which can be interpreted as ensuring access to food for every individual in fulfilling food needs in order to reach healthy life and doing various daily activities well. Instead of food insecurity means the weakness of each individual food access in fulfilling food needs. Insufficiency of food needs is influenced by food availability, distribution and food access. Wamena is the capital of Jayawijaya located in Baliem valley which is dominated by the Dani tribe. Baliem Valley is an upland valley $(1500-2000 \mathrm{~m} \mathrm{dpl})$. Sweet potato which is better known as hipere is the staple food of Dani. Farming and cultivation techniques applied is traditional ones and it has been done for generations. This research aims to assess and analyze the behavior of the people, entrepreneurial abilities and market orientation of farmers groups (wen mina hipere) toward the ability of cultivating farm fish and sweet potato. 


\section{Literature Review}

Entrepreneurial Orientation: Entrepreneurship is a process of doing something (creative), something different (innovative), and dare to take a risk (risk-taking). A creative entrepreneur related to the ability and tenacity to develop new ideas by combining their own resources, observe the previous situation and problem which are less attention (Thomas \& Scarborough, 2008). In addition, they tend to have many alternatives to face a particular situation and leverage mental omosional strength in order to create something or a new product or way and so on. Innovative is the application of creative ideas by taking the risk of what is done to get the opportunity in increasing business and profits by taking advantage of opportunities/potential of existing resources. Usually entrepreneurship is a process of development that is not related to the existing business company and done individually or together, but it is not as the inventor of production (Drucker, 2003). Other CE models proposed by Lumpkin and Dess $(1996 ; 135)$ states that there are five CE dimensions that affect the performance of companies/corporations, they are otonomy, innovation, willingness to take the risks, proactive, and competitive aggressiveness.

Market Orientation: According to Best (2004: 7), market orientation has three management characteristics that make it unique, such characteristics include; (a) customer focus, an obsession by understanding customers needs and member satisfaction, (b) competitor orientation, recognize the resource advantages of the competitors and competitors' marketing strategies continuously, (c) team approach, cross-functional group dedicated to develop and give solutions for customers. Market orientation has an important role in retaining customers and it also takes a competitive position. Customers who persist and new customers who successfully drawn will affect the company's market share. In addition, the real advantage is gained with a strong market orientation and high customer satisfaction. Maintaining or retaining the customers must be the top priority in a market-based management because satisfied and stand customers is the key of company profitability (Jaworski \& Kohli, 1990). According to Narver \& Slater (1990; 23), market orientation consists of three behavioral components - customer orientation, competitor orientation, and interfuctional coordination, and two decision criteria - long-term focus and profitability. Market orientation as more efficient competitive strategy is used to raise the company's behavior in creating high value for the customer and ensure the longer results for the company to its components are Customer Orientation, Competitor Orientation, and interfunctional coordination (Narver \& Slater, 1990; 23). The market orientation is valuable to the organization, because it makes the organization to focus on two things: (1) continuously collects information about consumers' needs and the ability of competitors; (2) uses this information to continually create superior value for customers.

Sistem Wen Mina Hipere (Farm of sweet potatoes and fishes): Dani in Baliem valley Jayawijaya, preserve local wisdom called Wen hipere to maintain the availability of sweet potato as the staple food as well as traditional culinary ingredient in a traditional ceremony called hekekit Ikhhogo (Randy efferputra, 2012). Sweet potatoes potential development through the use of Mina Wen Hipere technology which is studied by the researchers of BPTP Papua is quite large. Sweet potatoes planting area in Jayawijaya is 13210 ha with a production of 131915 tonnes while the land agriculture potential based on food crops is 4,251,058 ha (Sri et al., 2011). Innovation assembling carried out on sweet potatoes farming system (hipere) that has developed in Dani tribes, then they were introduced by fish farming technology (mina) in a canal of hipere garden. That is the reason why it is called as Mina Wen hipere. Technology package which is assembled includes modifications a large canal function as a barrier from the wild pigs in order to fulfill the qualification technic to grow tilapia. Fish feed is obtained from the leaves of sweet potatoes and cattle waste. Double benefit gained by the farmer are the increase of feasibility value on B/C of 1.87 and the source of protein from fish harvests. Mina Wen hipere has grown in villages spread over 4 districts in Jayawijaya. Assolokobal Districts are Hulekaima Village, Poteikeima Village, Uwanikaima Village and Wekiat Village. Other districts, Musakfak Village, Musafak District; Kepiatnem Village Hubikosi District; Kulegaima Village Hubikosi District; Kumina Village Kurulu District; and it is expected to spread more widely to all garden sweet potatoes with similar soil conditions with Baliem Valley. In order to accelerate the process technology adoption, BPTP Papua approaches traditional leaders as well as the facilitation and assistance with the decision taken by the farmers. Mina Wen Hipere farming systems technology implementation also likely to be developed into a farming system with agribusiness oriented. It is supported by the opening of the larger market opportunity 
along with the development of tourism industry in Baliem Valley Jayawijaya as one of the natural and cultural tourist destination in Papua (Jermia \& Soplanit, 2007).

\section{Methodology}

This research will be conducted in Wogo village, Silokarno District, Wamena-Jayawijaya, with the considerations: Dani tribes are generally farmers (wen mina hipere) of fish and sweet potato gardens which are better known as the staples food of Dani. Population is all of a group of farmers (wen mina hipere) who work as the farmers of sweet potatoes and freshwater fish (carp, catfish and tilapia) that exist in Wogi village, Silokarno district, Wamena. The sample of 20 farmers (wen mina hipere) of fish farm and sweet potatoes is determined through Proportionate cluster random sampling method. The sampling was conducted on a group of farmers (wen mina hipere)ofv fish and sweet potato gardens around Wogi village, Silokarno district, Wamena. Observed data include: the behavior of people in farming and freshwater fish farming, entrepreneurial abilities and market orientation of the farmers (wen mina hipere), diversification of agricultural land done by the farmers (wen mina hipere). Data collection method used is the field survey by using a direct observation system, structured interviews using questionnaires, unstructured interviews and FGD (Focus Group Discussion). In order to examine and analyze about: society behavior, entrepreneurial ability, market orientation and the factors that affect the group of the farmers (wen mina hipere) in Wogi village, Silokarno district, Wamena. The discussion will be conducted by multiple regression analysis.

\section{Findings and Discussion}

Characteristics of the respondents which is taken based on sex shows that the men has duty to clear the land and the women only help in to plant, maintenance and harvest. The average age of the respondents is 31-40 years old, which is considered as the productive age and they should be responsible to their family. Dani Tribes Farming Systems in Wamena is, sweet potatoes are planted on contour land will cause water retained on the seedbed, it causes sweet potatoes are not too sweet and they do not like the taste. In order to solve this problem, there is a socialization program on making contour land in the same direction to reduce the rate of erosion. However, the socialization was hampered because it is difficult to change the local culture that has been applied for hereditary. The longer and more time is needed to give insight to farmers about the dangers of erosion on land on the hillside. There was an introduction to plant other crops, in which the its seed obtained from tissue culture of Balitsa, corn and soybeans. All these plants are cultivated organically. They also been introduced to intercropping planting system. The introduction activity is expected to increase the resilience of the local people as well as providing an alternative food. The implementation of seedbeds is certainly expected to produce maximum crops. The soil structure is clay in Wamena. This condition causes flood in rainy day and dries quickly when it does not get rain. There is no irrigation system, the gardens rely on rain-fed systems. The results of soil preparation using a shovel and a fork in the form of chunks of land

Cropping patterns of Wen Mina hipere is (1) Land Preparation is done with the application of wen mina hipere technology packages, it can be seen from the creation of a rough mound above the ridges within 1 to $1.50 \mathrm{~m}$ and polished with mud removed from the canal around the seedbeds. Sweet potatoes (hipere) is planted on the mounds, while the water canal filled the fish (mina). Production potential reaches 15-20 t/ha, (2) Breeding preparation of sweet potatoes, taro and fish (carp, tilapia and catfish) in which the seeds obtained/purchased from the people/society so there is a varies price between one group of farmers with others. Fresh land is not be used directly after harvesting, they need enough time to break the land. With a total cost of Rp 26.500.000 during the production cycle, the profits reached Rp 39.900.000 with a value of $\mathrm{B} / \mathrm{C}$ is 1.5. it means that wen mina hipere farming is high financially profitable with a profit of $150 \%$ of the total costs incurred, in terms of food security, the application of mina wen hipere technology can provide staple food for families. they harvest sweet potato when they need it and the potatoes will be stored properly in the ground and harvest again when they need. Similarly, the fish will be harvested when the fish are big enough to be sold and the money used to buy rice and other food needs. Factors that have a significant effect on the ability of entrepreneurship farmers, Wen Mina hipere, are: Initiative $(b=0.471)$, perseverance $(b=$ $0.589)$, searching for information $(b=0.380)$, focus on the work $(b=0.471)$, commitment $(b=0.589)$, efficiency $(b=0.380)$, problem solving $(b=0.471)$, firmness $(b=0.337)$, consumer orientation $(b=0.589)$ and competitor orientation $(\mathrm{b}=0.380)$. While the factors that are not significantly influence in 
entrepreneurship skills of farmers Wen Mina hipere, are: Seeing and Taking Opportunities $(b=0.187)$, systematic planning $(b=0.176)$, confidence $(b=0.187)$, persuasive skills $(b=0.007)$, strategy $(b=0.125)$ and coordination with related agencies $(b=0.267)$.

\section{Conclusion}

Characteristics of the respondents, the men has the duty to clear and maintain the land while the women only help to prepare the seeds and harvest. The need of socialization of wen mina hipere pattern to the other farmers' groups, because by applying the pattern, the farmers will get benefit. Most crops of sweet potatoes, corn and fish can be sold and consumed by the family. The test results showed that the variables (1) viewing and taking opportunities, (2) systematic planning, (3) strategy to influence, (4) confidence, (5) persuasive ability, (6) Coordination with related agencies, they are not significantly affects the mindset of farmers on entrepreneurship. Variables that have a significant effect on the mindset of farmers on entrepreneurship are (1) competitor orientation, (2) Consumers Orientation, (3) specificity, (4) Orientation on efficiency, (4) work commitment, (5) Focus on high performance, (5) seeking information, (6) Persistence and (7) initiative, they give significant positive effects on the mindset of farmers on entrepreneurship. Dominant variables that make up the success of farmers in Wamena are persistence and work commitment. Entrepreneurship development and market orientation model that can be applied is by providing seedlings and land preparation, land cultivation mentoring, and consumer-oriented in harvest and improving coordination with related agencies for food security.

\section{References}

Best, R. J. (2004). Market Based Management, Strategies for Growing Customer Value and Profitability, Third Edition, Prentice Hall, Pearson Education International.

Drucker, P. F. (2003). Inovasi dan Kewiraswastaan: praktek dan dasar-dasar (Terjemahan: Innovation and Enterpreneurship oleh: RusjdiNaib) Penerbit Erlangga, Jakarta.

Jaworski, B. J. \& Kohli, A. K. (1990). Market Orientation: The Construct, Research Propositions and Management Implications. Journal of Marketing, 54, 1-18

Jermia, L. \& Soplanit, A. (2007). Ketersediaan Teknologi Dan Potensi pengembangan Ubi Jalar (Ipomoea batatas)) DI PAPUA. Jurnal Litbang Pertanian, 26(4)

Lumpkin, G. \& Dess, G. (1996). Clarifying the Entrepreneurial Orientation Construct and Linking it to Performance. Academy of Management Review, 21(1).

Narver \& Slater. (1990). The Effect of a Market Orientation on Business Profitability. Journal of Marketing, $20(10), 20-35$

Randy efferputra. (2012). blogspot.com/.../satu-lagi-tulisan-mengenai-salah-satu.ht...1 Sep 2012 - Wamena

Sri, R., Sihombing, A. S. \& Afrizal, M. (2011). Badan Penelitian Dan Pengembangan Pertanian Kementerian Pertanian,2011. Balai Pengkajian Teknologi Pertanian Papua

Thomas, W. Z. \& Scarborough, N. M. (2008). Kewirausahaan da Manajemen Usaha Kecil, (Terjemahan: Essentials of Entrepreneurship and Small Business Management oleh: Deny Arnos Kwary). Salemba Empat, 5(1). 